\title{
ECONOMIC MEASURES OF SERBIA AGAINST THE COVID-19 PANDEMIC
}

\author{
Tijana Radojevićc ${ }^{*}$, \\ Danica Rajin ${ }^{2}$, \\ Vladimir Brkić, \\ David Teraladze ${ }^{4}$ \\ ${ }^{1}$ Singidunum University, \\ Belgrade, Serbia \\ ${ }^{2} \mathrm{FEFA}$, \\ Belgrade, Serbia \\ ${ }^{3}$ SFS Financial Advisory Studio, \\ Belgrade, Serbia \\ ${ }^{4}$ RANEPA University, \\ Saint Petersburg, Russia
}

\begin{abstract}
:
An explosion of a coronavirus called COVID-19 has deranged the economy around the world. Due to the pandemic, there is great uncertainty regarding economic trends. Economic policy measures adopted by states should reduce uncertainty. When we talk about economic measures, we primarily look at helping the economy, the financial sector, and the population. However, it should be borne in mind that today we are facing an atypical crisis whereas the consequence we have is a reduced supply due to the measures adopted by the states, which primarily relate to the limited movement that affects business activity. The aim of the research in this paper is the economic measures adopted by the Republic of Serbia in the action against the consequences caused by COVID-19. Specifically, the paper discusses various packages of economic policy measures to minimize the negative effects caused by COVID-19 and provide support to the economy of Serbia.
\end{abstract}

Keywords:

economic measures, economic trends, financial crisis, COVID-19.

\section{Correspondence:}

Tijana Radojević

e-mail:

tradojevic@singidunum.ac.rs

\section{INTRODUCTION}

The pandemic COVID-19 triggered a health disaster that caused a global economic crisis. Measures taken by governments in all parts of the world to suppress the further transmission of the virus, have led to border closures, restrictions on movement, uncertainty in business activities, and cash flow problems in many companies, most notably in the most vulnerable industries such as tourism, transportation, hospitality, etc. In the economies of developed countries, there have been serious disturbances in the financial market due to the increasing demands imposed by the market immediately after the onset of the crisis. During the COVID-19 crisis, many companies around the world, including Serbia, were in a rush to use credit lines to provide the cash that was necessary for further business. Governments around the world and policymakers at the global level have reacted very quickly and adopted fiscal, monetary, and financial measures. The measures of the financial sector proved to be very important in combination with others because they were of great importance for supporting markets and solving the problem of financing companies.

The final consequence of the pandemic on the economy will depend on the financial sector and its ability to meet the demand of the corporate sector and avoid liquidity problems. Also, insufficient funds can lead to a reduction in business activities. 
Estimates of future economic trends and forecasts are changing daily, due to the inability to see the end of the health crisis and bringing the COVID-19 virus under control. There are different scenarios for future social and economic developments, which also depend on mitigating measures in later stages, as well as the length and severity of the pandemic and its impact on the world's leading economies. It is certain that the recession will be inevitable from today's perspective. However, its severity and recovery period are questionable.

\section{ECONOMIC DEVELOPMENTS IN THE WORLD BEFORE COVID-19}

Forecasts of global economic growth made at the end of 2019 indicated a possible slowdown in the global economy, as well as the economies of leading countries, during 2020 (United Nations, 2020). Factors that generated the slowdown were various uncertainties and risks related to conflict situations in the relations of leading economies in the field of trade relations (USA-China), uncertainties related to the economic policy of these countries, tensions in EU-Russia relations-imposed sanctions on Crimea annexation and the conflict in Ukraine, tensions within the EU over leaving Britain (Brexit), but also future EU perspectives, as well as standard environmental issues that have intensified over the past year. ${ }^{1}$ A special problem was the threat of new large-scale migrations of the population from the war-affected areas to Europe and the EU, especially from refugee camps in Turkey. The migrant problem has thus become a primary political issue in the relations between Turkey and the EU, but also between Turkey and Russia, of course with a certain influence of the United States, as the most politically and economically powerful country in the world. Concerns also stemmed from the extremely strained relations between the United States and Iran, which culminated in early 2020 (OECD Interim Economic Outlook, 2020). However, the global economic outlook changed and deteriorated completely when a new deadly SARSCoV-2 virus appeared in China, in Hubei province in early January, causing a disease called COVID-19 (Praščević, 2020).

\section{THE INFLUENCE OF COVID-19 ON THE ECONOMY}

The pandemic caused both short-term and long-term macroeconomic consequences. Macroeconomic costs and losses caused by the pandemic refer to the loss of gross domestic product (GDP) in the countries affected by the

1 Extreme temperatures in Australia, which caused fires at the end of the year, and a little earlier, a record number of fires were recorded in the Amazon rainforest, which generated an international crisis. epidemic, the growth of the unemployment rate in them, the deterioration of other macroeconomic variables fiscal indicators and external balance indicators, which will affect their economic growth rates. In addition to the uncertainty related to the ignorance of the future course of coronavirus infection, which makes it difficult to assess future economic trends, the uncertainty also refers to the ignorance of the impact that the exogenous pandemic shock factor will have on the economy because it is unique in modern economic history. Therefore, there is no experience with the impact of earlier similar triggers of the recession, and thus the coming recession can be considered atypical. In that context, the effects of measures of states that impose social distancing and the so-called "lockdown" of states, function as triggers for starting a recession, i.e., for prolonging it. That is why it is already called the "Great lockdown recession" (Praščević, 2020).

It is now a global pandemic that does not focus on lowincome countries, the world is much more integrated, interest rates are at an all-time low, and the current crisis is creating spillover effects in supply chains while collapsing supply and demand (Fernandes, 2020).

To realize the possible pessimistic economic influence of COVID-19, it is important to realize the economic transmission routes throughout whose collapses will have a negative impact on the economy. As stated by CarlssonSzlezak, Reeves \& Swartz (2020) there are three central transmission routes: (a) direct impact associated with lowered utilization of goods and services, (b) indirect impact acting through shocks in financial markets and their consequences on the actual economy and (c) supply-side disruptions.

\section{ECONOMIC POLICY DURING COVID 19}

An explosion of a coronavirus called COVID-19 has deranged the economy of China and continued to spread worldwide. The expansion of the infection and its economic influence is much undetermined, which makes it much more challenging for policy makers to develop a relevant strategy when it comes to macroeconomic policy.

Economic policy measures must primarily include both monetary and fiscal policy, to avoid aggregate demand being significantly affected after the aggregate supply has primarily suffered a shock. The pandemic COVID-19 will have short-term and long-term consequences. The long-term effects can certainly include the deterioration of public finances (public debt and the state budget deficit) because fiscal policy in all economies will be the backbone of economic policy in the fight against the consequences of pandemics. Therefore, it is estimated that deficits and public debt in most countries will reach levels that will exceed those from the time of the Great Global 
Recession (2007-09), from ten years ago, and which had negative economic consequences over a long period of time (sovereign debt crisis and austerity measures, the consequent recession in some economies - e.g., Greece, as well as the era of secular stagnation) (Praščević, 2017). EU countries are affected at different intensities, and the responses of countries are different, although they include fast and significant fiscal packages, with measures of the European Central Bank (ECB), as well as specific measures of national central banks. The response in the field of economic policy has, therefore, been present since the very beginning of the pandemic, both at the national levels of the members and at the level of the Union as a whole.

As part of the fiscal policy measures, it is left to national authorities to decide on, the EU has agreed to apply rule flexibility clauses that allow members to respond to significant fiscal stimulus to companies identified in the most affected economic sectors. The use of the EU budget is also envisaged, as well as its redirection and use of the Solidarity Fund budget (https://europa.eu/european-union/coronavirus-response_en).

\section{MEASURES OF SERBIA'S ECONOMIC POLICY AGAINST COVID-19}

Economic policy alone cannot end the crisis, but it has a key role to play: to protect livelihoods by preserving jobs and strengthening social safety nets (Marjanović \& Domazet, 2018). To alleviate the influence of the crisis, the Western Balkan countries have announced significant fiscal packages, ranging from 1 to 7 percent of GDP (without guarantees), in support of their citizens and businesses (Warwick \& Roshen, 2020). One of the questions is certainly, whether COVID-19 will generate a long-term modification in consumer behavior worldwide. It is already certain that the global decline in consumption and domiciliary requirements will be a huge test for the world economy (Goodell, 2020).

Until the COVID-19 crisis, Serbia had positive economic trends. Economic policy measures, economic indicators, and performance improved in the period before the pandemic, which led to a reduction in public debt to GDP, faster GDP growth, increased investment, and labor market performance. However, with the onset of the Covid crisis, everything slowed down both in Serbia and globally, and health care costs and other expenditures rose sharply.

Fiscal and monetary measures to prevent the unfavorable economic consequences of the pandemic have been introduced in 36 European countries and most countries in the world. These are: 1 ) tax policy measures; 2 ) measures of direct incentives from the budget and 3) measures for preserving liquidity (NALED Institute for Development and Innovation, 2020).
Serbia, like most countries, combined all groups of measures. The first package of measures included all three mentioned groups of assistance, while the second was a combination of the first two groups of measures, and the third included only direct benefits. The first and second packages of measures could be used by all economic entities that are not users of budget funds, while the third package was sectoral, intended for hotels and travel agencies. In Serbia, the total value of the package of measures introduced during 2020 is about $12.5 \%$ of GDP. For the most part, the measures were aimed at helping the population and the economy. The first package of measures is the "most expensive", bearing in mind that it covered the largest part of the economy and many measures, while the second can be seen as a supplement to the first. The most useful measures from the first package, according to economic entities, are direct payments in the form of payment of three minimum net salaries for all employees in micro, small and medium companies and entrepreneurs and postponement of social security contributions and payroll taxes until January 2021, after which they could be paid in 24 equal monthly installments. From the second package of measures, the most useful measure is the payment twice of $60 \%$ of the minimum net salary (NALED Institute for Development and Innovation, 2020).

The Government of Serbia has decided to introduce three packages of measures to support the economy in the fight against the crisis generated by the COVID-19 infection worth a total of 675.9 billion dinars. The first package of measures, as in most European countries, was a combination of all three groups of measures: tax policy measures, direct payments, and measures to maintain the liquidness of companies. This package of measures was of the highest value ( 608.3 billion dinars). The second package of measures was, again, a combination of measures, but this time a combination of two measures. It included tax policy measures and direct payments. This package of measures was significantly smaller than the first one (66 billion dinars). The third package of measures is the sector package, more precisely, it was focused only on companies that operate in the field of tourism, i.e., hotels and travel agencies. This package of measures is the smallest in size (1.6 billion dinars). 


\subsection{STATE ECONOMIC MEASURES PACKAGE TO REDUCE THE NEGATIVE CONSEQUENCES GENERATED BY THE COVID-19 PANDEMIC}

The Government of the Republic of Serbia has approved the following set of measures (Ministry of Finance of the Republic of Serbia, 2020):

\section{FIRST SET OF MEASURES:}

It assumes for the most part a delay in the disbursement of expected tax liabilities, with subsequent reimbursement in installments, starting in 2021:

- Postponement of payment of taxes and contributions on earnings is accomplished to maintain liquidity and employment rate.

All employers who choose to use this measure can use the deferral of payment of tax expenses and contributions to wages until the beginning of 2021, and after that, there is the possibility of further deferral of payment of these costs for up to 24 months without interest at the request of the taxpayer. The basic conditions for the application of this measure are identical for all employers, regardless of their economic strength.

- Delayed payment of advance income tax in the second quarter.

This measure intends to extend the liquidity of taxpayers by delaying the payment of advance income tax payments for 2020 that mature in the second quarter of 2020. The basic conditions for the application of this measure are identical for all corporate taxpayers, regardless of their economic strength.

- Donors are excepted from the commitment to pay VAT.

The aim of this measure is to release from VAT those donors who contribute with their commodity, to organizations that are precisely participating in actions intended at avoiding the transmit and handling citizens from COVID-19 infection.

As part of measures to preserve liquidity, a program of financial support to the economy has been established with the Development Fund in the amount of 24 billion dinars, and guarantee schemes for supporting the economy have been introduced. The program enables the granting of loans to economic entities to preserve liquidity and, consequently, the stability of the finances and economy of the Republic. The deadline for applications was until the reserved funds were distributed or no later than December 10, 2020. The repayment period of loans granted for these purposes is prescribed at a maximum of 36 months, of which 12 months is the grace period and 24 months of repayment, while the annual interest rate on the loan is $1 \%$.
The maximum loan amount is one million dinars for affiliated companies and 200,000 dinars for entrepreneurs, business entities and cooperatives. Micro, small and medium-sized enterprises that are privately owned, entrepreneurs and cooperatives that operate in the activities of production, provision of services, trade, or agriculture had the right to use these funds. Business entities operating in the field of games of chance, production or refining of oil and its derivatives did not have the right to apply to the Development Fund for this type of support. The conditions for obtaining the loan were that the company was not in bankruptcy proceedings, that it did not implement a reorganization plan prepared in advance, liquidation proceedings or financial restructuring. In addition, the business entity or company that applied for the loan was not allowed to lay off more than $10 \%$ of employees in relation to the number of employees in the period from March 15 to the expiration of three months from the release of credit funds for use. In addition to the stated conditions, the economic entity that has decided to use the loan may not pay dividends until the end of 2020. Loans were approved from the Development Fund in the total amount of almost nine billion dinars. According to the latest available data, loans for maintaining liquidity and working capital were approved for 1,856 business entities with over 30,000 employees, out of 2,195 registered (about $85 \%)$. Since mid-June, when special conditions for granting loans to companies operating in tourism, hospitality and passenger transport have been determined, the Fund keeps separate records on the number of legal entities and entrepreneurs from these activities that have applied for a loan and have been approved. The request for a loan was submitted by 298 business entities from the activities of tourism, hospitality, and passenger traffic, of which 253 (85\%) received a loan. $18 \%$ of the total approved loans were approved to companies from tourism, hospitality, and passenger transport (NALED Institute for Development and Innovation, 2020).

\section{SECOND SET OF MEASURES:}

It refers to direct payments to companies, payment of aid in the value of the minimum salary for entrepreneurs, micro, small and medium companies, regarding subsidies of 50 percent of the minimum salary to large companies, whose employees were sent on forced absence because of reduced business volume or total work stoppage.

In this set of measures, a difference was made in the manner of application based on the economic strength of the taxpayer. In accordance with that, entrepreneurs, micro, small and medium legal entities were given economic aid in the volume of the net minimum salary for each person who has the status of an employee. 
For legal entities that are classified as large, the assistance is determined in proportion to the number of persons that these employers keep in employment, although the need for their work has temporarily ceased.

The proposed measures sufficiently stimulate employers to maintain the existing level of employment, while in the case of entrepreneurs, small, micro and medium-sized legal entities, a larger scope of rights further strengthens liquidity in order to maintain business or abandon the initiation of termination proceedings.

\section{THIRD SET OF MEASURES:}

It is aimed at maintaining the liquidity of economic entities in the aspect of the economic confrontation forecasted during and after the end of the emergency caused by the COVID- 19 virus. With the program of these measures, the Serbian government wants to reduce external impacts, such as falling demand and disorder of supply chains, and their effects, such as diminishing employment and illiquidity, on the Serbian economy.

The program predicts two measures:

1) Program for allocating loans for protecting liquidity and working capital for entrepreneurs, micro, small and medium business entities, agricultural farms, and cooperatives that are enrolled in the relevant registry through the Development Fund of the Republic of Serbia.

2) Guarantee programs to encourage the economy in the COVID-19 crisis for loans to protect liquidity and working capital for companies in the segment of entrepreneurs, micro, small and medium enterprises, and likewise agricultural farms throughout commercial banks operating in the Republic of Serbia.

The overall value of the programs envisaged by this measure is 264 billion dinars (about 2.2 billion euros).

\section{FOURTH MEASURE SET:}

It refers to the payment of direct aid in the amount of 100 euros in dinar equivalent to all adult citizens of Serbia.

\section{CONCLUSION}

We can conclude that there was good communication between the economy and the Serbian Government, which was conditioned by monitoring changes in the market at the time and which led to harmonization and adoption of economic measures that could meet the real needs of the economy and citizens, in order to overcome the economic shocks that coronavirus brought to us.

When we talk about the projection of future economic trends, it is impossible to make a good projection since economic trends in Serbia and in the world depend on the current health crisis, the impact of economic measures, restrictions imposed, but also the expectations of investors and consumers. It remains unclear whether the recession will save small and medium-sized enterprises or whether the focus will be on big capital and how to preserve banks. Some industries have suffered strong economic shocks due to limited or complete inability to move employees, capital, products and services.

There is an evident and reduced consumption on the market, which in the future can lead to a slowdown in production and construction of entire plants, because companies will have nowhere to place their products. This leads to a complete slowdown in economic turnover. The next period will show how capable and strong the states are to protect and not allow the takeover of strategically important companies, and how much they will succeed in preventing monopolistic expansion. Looking at both Serbia and other countries on a global level, it is inevitable that, as in 2020 and 2021, losses will be incurred, and will be compensated only when the market is fully stabilized. Until then, Serbia must be ready for new economic measures if there is a restriction of movement and work.

\section{LITERATURE}

Carlsson-Szlezak, P., Reeves, M., \& Swartz, P. (2020) Understanding the Economic Shock of Coronavirus, Harvard Business Review, Available at https://hbr.org/2020/03/ understanding-the-economic-shock-of-coronavirus

Fernandes, N. (2020) Economic Effects of Coronavirus Outbreak (COVID-19) on the World Economy. IESE Business School Working Paper No. WP-1240-E, Available at SSRN: https://ssrn.com/abstract=3557504

Goodell J. W. (2020) COVID-19 and finance: Agendas for future research. Finance research letters, 35, 101512. https://doi.org/10.1016/j.frl.2020.101512

Marjanović, D. \& Domazet, I. (2018) Unapređenje makro konkurentnosti - fiskalni aspekti. Beograd: Institut ekonomskih nauka

Ministarstvo finansija Republike Srbije (2020). Program ekonomskih mera za smanjivanje negativnih efekata prouzrokovanih pandemijom virusa COVID $19 \mathrm{i}$ podršku privredi Srbije, https://www.mfin.gov.rs/aktivnosti/ministar-finansijapredstavio-program-ekonomskih-mera-zapodrsku-privredi-srbije-i-smanjivanje-negativnihefekata-prouzrokovanih-pandemijom-virusa-kovid-19

NALED Institut za razvoj i inovacije (2020). Efekti ekonomskih mera za ublažavanje negativnih posledica COVID-19 na privredu, https://naled.rs/htdocs/Files/06839/ Analiza_efekata_ekonomskih_mera_za_ublazavanje_ negativnih_posledica_COVID-19_na_privredu.pdf 
OECD Interim Economic Outlook (2020). Coronavirus: The world economy at risk. https://www.oecd.org/ berlin/publikationen/Interim-Economic-Assessment2-March-2020.pdf

Praščević, A. (2017) Od globalne ekonomske krize do krize globalnog kapitalizma, Ekonomske ideje i praksa, Vol. 24, pp. 7-21

Praščević, A. (2020) Ekonomski šok pandemije COVID 19 - prekretnica u globalnim ekonomskim kretanjima, Ekonomske ideje i praksa, Vol.37, pp. 7-22
United Nations (2020). World Economic Situation and Prospects 2020. Sales No. E.20. II.C.1. https://www.un.org/ development/desa/dpad/wp-content/uploads/sites/45/ publication/WESP2020_FullReport_web.pdf

Warwick J.M. \& Roshen, F. (2020) The Global Macroeconomic Impacts of COVID-19: Seven Scenarios. CAMA Working Paper No. 19/2020. Available at SSRN: https:// ssrn.com/abstract=3547729

https://europa.eu/european-union/coronavirus-response_en 